\title{
ESTIMASI HERITABILITAS SIFAT PERTUMBUHAN DOMBA EKOR GEMUK DI UNIT PELAKSANA TEKNIS PEMBIBITAN TERNAK-HIJAUAN MAKANAN TERNAK GARAHAN
}

\author{
HERITABILITY ESTIMATION OF GROWTH TRAITS OF FAT TAILED SHEEP AT UNIT \\ PELAKSANA TEKNIS PEMBIBITAN TERNAK-HIJAUAN MAKANAN TERNAK GARAHAN
}

\author{
Sumadi*, Jatmika Prajayastanda, dan Nono Ngadiyono \\ Fakultas Peternakan, Universitas Gadjah Mada, Jl. Fauna No. 3, Bulaksumur, Yogyakarta, 55281
}

\section{INTISARI}

Domba adalah salah satu ternak ruminansia yang populer di Indonesia, karena merupakan salah satu sumber protein hewani, mudah dikembangbiakkan dan mudah dalam pemuliaan, oleh karena itu perlu dikembangkan, dilestarikan dan ditingkatkan produktivitasnya melalui peningkatan mutu genetik dengan cara melakukan seleksi dan pengaturan perkawinan yang tertuang di dalam program breeding. Penyusunan program breeding memerlukan nilainilai parameter genetik yaitu heritabilitas. Tujuan penelitian ini adalah untuk mengestimasi nilai heritabilitas sifat pertumbuhan domba Ekor Gemuk (DEG) di Unit Pelaksana Teknis Pembibitan Ternak-Hijauan Makanan Ternak (UPT PT-HMT) Garahan, Jember, Jawa Timur. Data yang digunakan adalah data silsilah, bobot lahir, dan bobot sapih DEG di UPT-HMT Garahan, Jember dari tahun 2007 sampai 2012. Data yang diperoleh dikoreksi terhadap jenis kelamin, tipe kelahiran, dan umur sapih. Analisis data untuk heritabilitas dengan metode saudara tiri sebapak dan pola tersarang. Hasil estimasi nilai heritabilitas menggunakan metode korelasi saudara tiri sebapak sebesar 0,85 $\pm 0,39$ untuk bobot lahir,

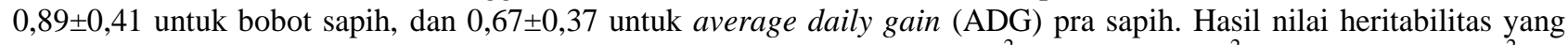
didapatkan dengan metode pola tersarang berturut-turut adalah $0,89 \pm 0,48\left(\mathrm{~h}_{\mathrm{S}}^{2}\right),-0,11 \pm 0,33\left(\mathrm{~h}_{\mathrm{D}}^{2}\right)$, dan $0,39 \pm 0,28\left(\mathrm{~h}^{2}{ }_{\mathrm{S}+\mathrm{D}}\right)$

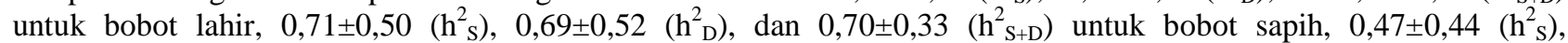
$0,72 \pm 0,56\left(\mathrm{~h}_{\mathrm{D}}^{2}\right)$, dan $0,60 \pm 0,32\left(\mathrm{~h}_{\mathrm{S}+\mathrm{D}}^{2}\right)$ untuk ADG pra sapih. Hasil penelitian ini menunjukkan bahwa nilai heritabilitas DEG di UPT PT-HMT Garahan, Jember termasuk kategori tinggi.

(Kata kunci: Domba Ekor Gemuk, Heritabilitas, Sifat pertumbuhan)

\section{ABSTRACT}

Sheep is one of popular ruminants in Indonesia, because sheep is one one of source of animal protein, and also easy and convenient in breeding. Therefor, they should be developed, preserved and increased through improvement of genetic quality by selection and mating control in the breeding program. Arrangement of a breeding program requires the values of genetic parameter namely heritability. The purpose of this study was to estimate the growth heritability value of Fat Tailed sheep in UPT PT-HMT Garahan, Jember, East Java. Data were collected from progeny, birth weight and weaning weight of Fat Tailed sheep from 2007 to 2012 in UPT-HMT Garahan, Jember. Data were corrected by sex, type of birth and weaning of age. Data were analyzed using the heritability of paternal halfsib correlations and nested method of analysis. The estimation of heritabilities using paternal halfsib correlation were $0.85 \pm 0.39 ; 0.89 \pm 0,41$ and $0.67 \pm 0.37$ for birth weight, weaning weight and pre weaning average daily gain (ADG). While, heritabilities estimated from nested method were $0.89 \pm 0,48\left(h_{S}^{2}\right) ;-0.11 \pm 0.33\left(h_{D}^{2}\right) ; 0.39 \pm 0.28\left(h_{S+D}^{2}\right)$; $0.71 \pm 0.50\left(h_{S}^{2}\right) ; 0.69 \pm 0.52\left(h_{D}^{2}\right) ; 0.70 \pm 0.33\left(h^{2}{ }_{S+D}\right) ; 0.47 \pm 0.44\left(h_{S}^{2}\right) ; 0.72 \pm 0.56\left(h_{D}^{2}\right) ; 0.60 \pm 0.32$ ( $\left.h^{2}{ }_{S+D}\right)$ for birth weight, weaning weight an pre weaning $A D G$, respectively. All growth heritabilities of Fat Tailed sheep in high category.

(Keyword: Fat Tailed sheep, Growth characters, Heritability)

\section{Pendahuluan}

Produktivitas pada domba Ekor Gemuk (DEG) dipengaruhi faktor genetik, lingkungan, dan interaksi keduanya. Produktivitas pada ternak merupakan gabungan sifat produksi dan reproduksi dan dapat ditingkatkan melalui perbaikan mutu genetik atau perbaikan lingkungan dan umumnya melalui dua-duanya (Warwick et al., 1990 dan Hardjosubroto, 1994).

Pada program swasembada daging sapi dan kerbau (PSDSK) tahun 2014 di Indonesia, daging domba dapat dijadikan alternatif untuk kecukupan daging sehingga ternak DEG perlu ditingkatkan produktivitasnya. Domba Ekor Gemuk merupakan ternak ruminansia kecil yang cukup potensial untuk dikembangkan dan dilestarikan keberadaannya.

\footnotetext{
*Korespondensi (corresponding author):

Telp. +62 81328832260

E-mail: profsumadi@yahoo.co.id
} 
Keunggulan DEG dibandingkan ruminansia besar adalah calving interval yang pendek, prolific (beranak lebih dari satu), daya adaptasi yang tinggi di iklim tropis dan mudah pemeliharaannya.

Domba Ekor Gemuk adalah salah satu domba yang popular di Indonesia sebagai penghasil daging. Populasi DEG terbesar di Indonesia adalah di Jawa Timur dan provinsi ini juga terdapat unit pelaksana teknis pembibitan DEG, yaitu di Unit Pelaksana Teknis Pembibitan Ternak-Hijauan Makanan Ternak (UPT PT-HMT), Garahan, Jember dengan tupoksi melakukan seleksi untuk menghasilkan DEG yang unggul dalam produksi dan reproduksi.

Pertambahan bobot badan harian (PBBH) atau pertumbuhan pada DEG merupakan salah satu sifat produksi yang bernilai ekonomi tinggi dan banyak dipengaruhi genetik, lingkungan dan interaksi keduanya. Pengaruh faktor genetik pada pertumbuhan bersifat baka, artinya tidak akan berubah selama hidupnya, sepanjang tidak terjadi mutasi gen yang menyusunnya dan pengaruh faktor genetik dapat diwariskan kepada keturunannya yang dapat diukur dengan heritabilitas. Kusumo (2004) di UPT PT-HMT Garahan, mengestimasi nilai heritabilitas bobot lahir, bobot sapih, dan average daily gain (ADG) pra sapih pada DEG, masing-masing sebesar $0,041 \pm 0,26 ;-0,16 \pm 0,19$ dan $-0,22 \pm 0,18$. Oleh karena itu, estimasi nilai heritabilitas sifat pertumbuhan pada DEG secara berkala dapat digunakan sebagai salah satu kriteria seleksi untuk peningkatan produktivitasnya.

Penelitian ini bertujuan untuk mengestimasi nilai heritabilitas $\left(\mathrm{h}^{2}\right)$ bobot lahir dan bobot sapih DEG di UPT PT-HMT Garahan, Jember, Jawa Timur.

\section{Materi dan Metode}

\section{Materi penelitian}

Materi yang digunakan dalam penelitian adalah data silsilah, bobot lahir, dan bobot sapih dari 123 anak DEG yang terdiri dari 57 jantan dan 66 betina yang berasal dari 16 ekor pejantan dan 41 ekor induk di UPT PT-HMT Garahan, Jember, Jawa Timur.

\section{Metode}

Penelitian ini dilakukan dengan menggunakan catatan data yang meliputi bobot lahir dan bobot sapih (umur 90 hari) di UPT PT-HMT Garahan, Jember. Pendugaan angka pewarisan atau heritabilitas dilakukan dengan analisis variansi dengan menggunakan data saudara tiri sebapak (paternal halfsib correlation). Average daily gain pra sapih dihitung dengan cara bobot sapih dikurangi bobot lahir kemudian dibagi umur sapih (hari).
Bobot lahir dan bobot sapih dikoreksi terhadap jenis kelamin, umur induk dan tipe kelahiran. Berdasarkan jumlah data yang cukup, faktor koreksi umur jenis kelamin dan tipe kelahiran dibuat menggunakan data yang ada. Koreksi terhadap jenis kelamin dilakukan dengan cara sebagai berikut: rerata bobot lahir cempe jantan dibagi dengan rerata bobot lahir cempe betina. Hasil perhitungan tersebut digunakan untuk mengalikan individu betina, sedangkan anak jantan menggunakan bobot lahir asal (Sumadi, 1985). Faktor koreksi untuk tipe kelahiran dihitung dengan mengalikan bobot lahir cempe dengan angka 1,15 untuk kelahiran kembar dan sistem pemeliharaan kembar, 1,10 untuk kelahiran kembar dengan sistem pemeliharaan tunggal dan 1,00 untuk kelahiran tunggal (Hardjosubroto, 1994).

\section{Analisis data}

Data bobot lahir dan bobot sapih dikoreksi terhadap jenis kelamin, tipe kelahiran, umur induk seperti koreksi pada bobot lahir dan terhadap umur sapih 90 hari. Rumus yang digunakan untuk melakukan penyesuaian adalah sebagai berikut (Hardjosubroto, 1994):

$$
\begin{aligned}
\mathrm{BLT} & =\text { BLN } x \text { FKJK } x \text { FKTL } x \text { FKUI } \\
\mathrm{BST} & =[\text { BLN }+\{(\mathrm{BSN}-\mathrm{BLN}) / \text { umur } \mathrm{x} 90\}] \\
& \text { FKJK } \mathrm{x} \text { FKUI } \mathrm{x} \text { FKTL } \\
\mathrm{PsbS} & =(\mathrm{BST}-\mathrm{BLT}) / 90
\end{aligned}
$$

Keterangan:

BLT = bobot lahir terkoreksi

BLN = bobot lahir nyata

FKJK = faktor koreksi jenis kelamin

FKUI $=$ faktor koreksi umur induk

FKTL = faktor koreksi tipe kelahiran

BST = bobot sapih terkoreksi

BSN = bobot sapih nyata

Umur = rerata umur sapih

$\mathrm{PsbS}=$ pertumbuhan sebelum sapih

Pengukuran estimasi nilai heritabilitas diukur menggunakan dua metode yaitu: korelasi saudara tiri sebapak (paternal halfsib correlation) dan metode tersarang (nested method).

Metode korelasi saudara tiri sebapak. Analisis yang digunakan dalam estimasi heritabilitas dengan metode korelasi saudara tiri sebapak adalah Rancangan Acak Lengkap pola searah (Completely Randomized Design One-Way classification) dengan model statistik menurut Becker (1992) sebagai berikut:

$$
\mathrm{Y}_{\mathrm{ik}}=\mu+\alpha_{\mathrm{i}}+\mathrm{e}_{\mathrm{ik}}
$$

Keterangan:

$\mathrm{Y}_{\mathrm{ik}}=$ performa individu ke-k pada pengukuran ke-i 
$\mu=$ mean

$\alpha_{\mathrm{i}}=$ pengaruh individu ke-i

$\mathrm{e}_{\mathrm{ik}}=$ simpangan lingkungan dan genetik dari pengukuran di dalam suatu individu.

Pemisahan komponen ragam untuk menduga nilai heritabilitas dilakukan dengan analisis sidik ragam Rancangan Acak Lengkap (RAL). Model sidik ragam untuk menghitung nilai heritabilitas (h2) dengan menggunakan saudara tiri sebapak.

Nilai heritabilitas:

$$
\begin{gathered}
\sigma_{\mathrm{W}}^{2}=\mathrm{MS}_{\mathrm{w}} \\
\sigma_{\mathrm{W}}^{2}=\frac{M S s-M S w}{k} \\
\mathrm{k}=\frac{1}{\sigma-1}\left(n \cdot-\frac{\sum n i^{2}}{n .}\right)
\end{gathered}
$$

Dari komponen-komponen ini, korelasi dalam kelas yaitu suatu ukuran kemiripan antar saudara tiri dapat ditentukan sebagai berikut:

$$
\mathrm{t}=\frac{\sigma^{2} \mathrm{~s}}{\sigma^{2} \mathrm{~s}+\sigma^{2} \mathrm{w}}
$$

Rumus menghitung heritabilitas adalah sebagai berikut:

$$
\mathrm{h}^{2}=\frac{4 \sigma^{2} \mathrm{~s}}{\sigma^{2} \mathrm{~s}+\sigma^{2} \mathrm{w}}
$$

Standar error heritabilitas korelasi saudara tiri sebapak dihitung menggunakan rumus:

$$
\mathrm{SE}\left(\mathrm{h}^{2}\right)=4 \sqrt{\frac{2(1-t)^{2}(1+(k-1) t)^{2}}{k(k-1)(s-1)}}
$$

Metode tersarang (nested method). Pemisahan komponen ragam untuk menduga nilai heritabilitas dilakukan dengan analisis pola tersarang. Model sidik ragam untuk menghitung nilai heritabilitas $\left(\mathrm{h}^{2}\right)$ dengan menggunakan korelasi saudara kandung dengan metode pola tersarang sesuai rekomendasi Becker (1992) sebagai berikut:

$$
Y_{i j k}=\mu+\alpha_{i}+\beta_{i j}+e_{i j k}
$$

Keterangan:

$$
\begin{aligned}
\mathrm{Y}_{\mathrm{ijk}}= & \text { data dari anak ke-k dari induk ke-j dengan } \\
& \text { pejantan } \mathrm{i} \\
\mu & \text { rerata } \\
\alpha_{\mathrm{i}} & \text { pengaruh pejantan ke- } \mathrm{i} \\
\beta_{\mathrm{ij}} & =\text { pengaruh induk ke- } \mathrm{j} \text { dengan pejantan ke- } \mathrm{i} \\
\mathrm{e}_{\mathrm{ijk}} & =\text { penyimpangan pengaruh lingkungan dan } \\
& \text { genetik yang tidak terkontrol. }
\end{aligned}
$$

Untuk perhitungan heritabilitas digunakan rumus:

$$
\sigma_{\mathrm{w}}^{2} \quad=\mathrm{MS}_{\mathrm{w}}
$$

$$
\begin{array}{ll}
\sigma_{D}^{2} & =\frac{M S_{D^{-}} M S_{W}}{k_{1}} \\
\sigma_{S}^{2} & =\frac{M S_{S}-\left(M S_{w}+k_{2} \sigma_{D}^{2}\right)}{k_{3}} \\
k_{1} & =\frac{n . .-\sum\left(\sum n_{i j}^{2} / n_{i}\right)}{d f(\text { induk })} \\
k_{2} & =\frac{\sum\left(\sum n_{i j}^{2} / n_{i}\right)-\left(\sum \sum n_{i j}^{2}\right)}{d f(p e j a n t a n)} \\
k_{3} & =\frac{n . .-\left(\sum n_{i .}^{2}\right)}{d f(p e j a n t a n)} \\
h^{2}{ }_{S} & =\frac{4 \sigma_{S}^{2}}{\sigma_{S}^{2}+\sigma_{D}^{2}+\sigma_{w}^{2}} \\
h^{2} & =\frac{4 \sigma_{D}^{2}}{\sigma_{S}^{2}+\sigma_{D}^{2}+\sigma_{w}^{2}} \\
h^{2}{ }_{(S+D)} & =\frac{2\left(\sigma_{S}^{2}+\sigma_{D}^{2}\right)}{\sigma_{S}^{2}+\sigma_{D}^{2}+\sigma_{w}^{2}}
\end{array}
$$

Standard error metode korelasi saudara kandung dapat dihitung dengan rumus:

$$
S E h^{2}=\frac{2 \sqrt{\operatorname{var} \sigma_{\mathrm{S}}^{2}+\operatorname{var} \sigma_{\mathrm{D}}^{2}-2 \operatorname{cov}\left(\sigma_{\mathrm{S}}^{2}+\sigma_{\mathrm{D}}^{2}\right)}}{\sigma_{\mathrm{S}}^{2}+\sigma_{\mathrm{D}}^{2}+\sigma_{\mathrm{w}}^{2}}
$$

\section{Hasil dan Pembahasan}

\section{Bobot lahir, bobot sapih, dan average daily gain (ADG) pra sapih}

Rerata bobot lahir, bobot sapih dan ADG pra sapih di UPT PT-HMT Garahan, Jember, Jawa Timur tersaji pada Tabel 3. Hasil pengukuran dari bobot sapih, bobot lahir, dan ADG pra sapih bisa dilihat bahwa ternak domba jantan mempunyai bobot lahir dan bobot sapih yang relatif lebih tinggi dibandingkan domba betina, serta pertumbuhan domba jantan lebih cepat dibandingkan dengan domba betina.

Bobot lahir. Rerata bobot lahir DEG pada penelitian ini yaitu $2,31 \pm 0,59 \mathrm{~kg}$ dan bobot lahir domba setelah dikoreksi nilai reratanya yaitu $3,09 \pm 0,67 \mathrm{~kg}$ (Tabel 3). Hasil rerata bobot lahir domba jantan lebih tinggi dibandingkan dengan bobot lahir domba betina, dengan bobot lahir masing-masing 2,34 $\pm 0,62 \mathrm{~kg}$ untuk domba jantan dan 2,28 $\pm 0,57 \mathrm{~kg}$ untuk domba betina. Setelah dianalisis tidak ada perbedaan nyata antara bobot lahir domba jantan dengan domba betina.

Induk muda selama kebuntingan pertama masih dalam masa pertumbuhan, sehingga bersaing dengan fetus untuk bahan makanan yang tersedia (Toelihere, 1981). Di samping itu, bertambahnya umur induk cenderung meningkatkan bobot lahir keturunannya (Lasley, 1978). 
Tabel 1. Analisis keragaman untuk estimasi heritabilitas dengan pola Rancangan Acak Lengkap (analysis of variance to estimate the heritability of the Completely Randomized Design patterns)

\begin{tabular}{|c|c|c|c|c|c|}
\hline \multicolumn{2}{|r|}{ Sumber keragaman (source of diversity) } & df & SS & MS & EMS \\
\hline \multirow{2}{*}{\multicolumn{2}{|c|}{$\begin{array}{l}\text { Pejantan }(\text { sire })(\mathrm{s}) \\
\text { Keturunan dalam pejantan (offspring within } \\
\text { sire })(\mathrm{w})\end{array}$}} & S - 1 & $\mathrm{SS}_{\mathrm{S}}$ & $\mathrm{MS}_{\mathrm{S}}$ & $\sigma_{\mathrm{W}}^{2}+\mathrm{k} \sigma^{2}$ \\
\hline & & n. $-\mathrm{S}$ & $\mathrm{SS}_{\mathrm{W}}$ & $\mathrm{MS}_{\mathrm{W}}$ & $\sigma_{\mathrm{w}}^{2}$ \\
\hline $\mathrm{k}$ & \multicolumn{5}{|c|}{$=$ jumlah keturunan per pejantan (number of progeny per sire) } \\
\hline S & \multicolumn{5}{|c|}{$=$ jumlah pejantan (number of sire) } \\
\hline n. & \multicolumn{5}{|c|}{$=$ jumlah individu (number of individu) } \\
\hline$\sigma^{2}{ }^{2}$ & \multicolumn{5}{|c|}{$=$ komponen ragam antar anak dalam pejantan (the variation component progeny within sire) } \\
\hline$\sigma_{s}^{2}$ & \multicolumn{5}{|c|}{$=$ komponen ragam antar pejantan (the variation component within sire) } \\
\hline df & \multicolumn{5}{|c|}{$=$ derajat bebas (degrees of freedom) } \\
\hline SS & \multicolumn{5}{|l|}{$=$ jumlah kuadrat $($ sum of square $)$} \\
\hline MS & \multicolumn{5}{|c|}{$=$ kuadrat tengah (mean of square) } \\
\hline EMS & \multicolumn{5}{|c|}{$=$ hasil kali rerata harapan (expected mean squares). } \\
\hline
\end{tabular}

Tabel 2. Analisis keragaman untuk estimasi heritabilitas dengan pola tersarang (nested) (analysis of variance to estimate the heritability of a nested pattern (nested))

\begin{tabular}{|c|c|c|c|c|}
\hline Sumber keragaman (source of diversity) & df & SS & MS & EMS \\
\hline Pejantan (sire) (s) & S - 1 & $\mathrm{SS}_{\mathrm{S}}$ & $\mathrm{MS}_{\mathrm{S}}$ & $\sigma_{W}^{2}+k_{2} \sigma_{D}^{2}+k_{3} \sigma_{D}^{2}$ \\
\hline $\begin{array}{l}\text { Antar induk dalam pejantan (between dams within } \\
\text { sires) }\end{array}$ & $\mathrm{D}-\mathrm{S}$ & $\mathrm{SS}_{\mathrm{D}}$ & $\mathrm{MS}_{\mathrm{D}}$ & $\sigma^{2}{ }_{w}+k_{1} \sigma_{D}^{2}$ \\
\hline $\begin{array}{l}\text { Antar keturunan dalam induk (between progeny } \\
\text { within dams) }\end{array}$ & n.. $-\mathrm{d}$ & $\mathrm{SS}_{\mathrm{W}}$ & $\mathrm{MS}_{\mathrm{W}}$ & $\sigma^{2}{ }_{w}$ \\
\hline
\end{tabular}

$\mathrm{S} \quad=$ jumlah pejantan (number of sire)

$\mathrm{D} \quad=$ jumlah induk (number of dam)

n.. $\quad=$ jumlah individu (number of individu)

$\mathrm{k}_{1}=\mathrm{k}_{2}=$ jumlah keturunan per pejantan (number of progeny per sire)

$\mathrm{k}_{3} \quad=$ jumlah keturunan per induk (number of progeny per dam)

$\sigma_{\mathrm{w}}^{2} \quad=$ komponen ragam antar anak dalam pejantan (the variation component progeny within sire)

$\sigma_{S}^{2} \quad=$ komponen ragam antar pejantan (the variation component within sire)

$\sigma^{2}{ }_{D} \quad=$ komponen ragam antar induk (the variation component within dam)

df $\quad=$ derajat bebas (degrees of freedom)

SS = jumlah kuadrat (sum of square)

MS = kuadrat tengah (mean of square)

EMS = hasil kali rerata harapan (expected mean squares).

Bobot sapih. Rerata bobot sapih DEG pada penelitian ini yaitu $11,54 \pm 3,22 \mathrm{~kg}$ dan rerata bobot sapih yang sudah dikoreksi yaitu $14,42 \pm 3,41 \mathrm{~kg}$. Hasil rerata bobot sapih domba jantan lebih tinggi dibandingkan dengan bobot sapih domba betina, dengan bobot sapih masing-masing 12,06 $\pm 3,19 \mathrm{~kg}$ untuk domba jantan dan $11,09 \pm 3,19 \mathrm{~kg}$ untuk domba betina (Tabel 3). Setelah dianalisis menunjukkan adanya perbedaan nyata antara bobot sapih domba jantan dengan domba betina $(\mathrm{P}<0,05)$.

Bobot lahir domba berpengaruh terhadap laju pertumbuhan pra sapihnya. Anak domba dengan bobot lahir rendah biasanya diikuti oleh rendahnya air susu yang diperoleh dari induknya, sehingga laju pertumbuhan sampai disapih terlihat lebih lambat daripada anak domba yang bobot lahirnya tinggi. Perbedaan bobot lahir domba sebesar $1 \mathrm{~kg}$ akan menghasilkan perbedaan bobot sapih antara 3 sampai 4 kg (Edey, 1983).

Pertumbuhan ternak diatur oleh hormon baik secara langsung maupun tidak langsung (Soeparno, 2009). Pertumbuhan tulang dan metabolisme nitrogen dipengaruhi secara langsung oleh hormon antara lain somatotropin, tiroksin, androgen, estrogen dan glukokortikoid (GK) (Hafez dan Dyer, 1969). Sekresi hormon testosteron yang tidak menyebabkan sekresi androgen ikut naik sehingga hormon ini mengakibatkan pertumbuhan yang lebih cepat pada ternak jantan terutama munculnya sifatsifat kelamin sekunder.

Average daily gain pra sapih. Average daily gain pra sapih DEG pada penelitian ini yaitu $0,10 \pm 0,03 \mathrm{~kg}$, sedangkan ADG pra sapih menggunakan bobot lahir dan bobot sapih yang 
Tabel 3. Rerata bobot lahir, bobot sapih, dan ADG pra sapih domba Ekor Gemuk (average of birth weight, weaning weight and $A D G$ of pre-weaning on Fat Tailed sheep)

\begin{tabular}{lcc}
\hline \multicolumn{1}{c}{ Sifat (trait) } & Jumlah (n) (number) & Rerata \pm SE $(\mathrm{kg})($ mean \pm SE $(\mathrm{kg}))$ \\
\hline Bobot lahir (birth weight) & 57 & $2,34 \pm 0,62$ \\
Jantan (male) & 66 & $2,28 \pm 0,57$ \\
Betina (female) & 123 & $2,31 \pm 0,59$ \\
Total & 123 & $3,09 \pm 0,67$ \\
Terkoreksi (corrected) & & \\
Bobot sapih (weaning weight) & 67 & $12,06 \pm 3,19$ \\
Jantan (male) & 66 & $11,09 \pm 3,19$ \\
Betina (female) & 123 & $11,54 \pm 3,22$ \\
Total & 123 & $14,42 \pm 3,41$ \\
Terkoreksi (corrected) & 67 & \\
ADG pra sapih (ADG pre-weaning) & 66 & $0,11 \pm 0,03$ \\
Jantan (male) & 123 & $0,10 \pm 0,03$ \\
Betina (female) & 123 & $0,10 \pm 0,03$ \\
Total & & $0,13 \pm 0,03$ \\
Terkoreksi (corrected) &
\end{tabular}

ADG: average daily gain, SE: standard error.

sudah terkoreksi mendapatkan hasil $0,13 \pm 0,03 \mathrm{~kg}$. Pertambahan bobot badan harian dipengaruhi oleh genetik, bobot lahir, umur induk, produksi susu induk, jumlah anak sekelahiran, jenis kelamin anak dan umur sapih (Edey, 1983).

Hasil penelitian ini juga menunjukkan rerata pertambahan bobot badan pra sapih domba jantan lebih tinggi daripada domba betina (Tabel 3). Rerata pertambahan bobot badan perhari domba jantan sebesar $0,11 \pm 0,03 \mathrm{~kg}$ sedangkan domba betina $0,10 \pm 0,03 \mathrm{~kg}$.

Pertambahan bobot badan dipengaruhi oleh jenis kelamin. Pertambahan bobot badan domba jantan umumnya lebih besar daripada domba betina, karena perbedaan pada sistem hormonal. Hormon testosteron pada domba jantan dapat meningkatkan daya ikat cytosol dari musculus gluteus yang berhubungan dengan metabolisme protein. Pertumbuhan ternak betina lebih lambat daripada ternak jantan, karena hormon estrogen yang terdapat pada ternak betina membatasi pertumbuhan tulang-tulang pipa dan adanya hormon androgen yang membatasi perlemakan (Toelihere, 1981).

\section{Estimasi heritabilitas}

Heritabilitas sifat pertumbuhan DEG berdasarkan catatan produksi milik UPT PT-HMT Garahan, Jember, Jawa Timur diestimasi dengan metode korelasi saudara tiri sebapak (paternal halfsib correlation) dan metode pola tersarang (nested). Hasil estimasi heritabilitas bobot lahir $\left(\mathrm{h}^{2}{ }_{\mathrm{BL}}\right)$, bobot sapih $\left(\mathrm{h}_{\mathrm{BS}}^{2}\right)$ dan $\mathrm{ADG}$ pra sapih ( $\mathrm{h}^{2}$ PsbS $)$ tersaji pada Tabel 4.
Estimasi heritabilitas bobot lahir. Estimasi heritabilitas bobot lahir dengan metode korelasi saudara tiri sebapak nilai heritabilitasnya sebesar $0,85 \pm 0,39$. Nilai heritabilitas yang tinggi dan positif menunjukkan bahwa korelasi antar ragam genetik aditif dengan ragam fenotip cukup tinggi sehingga apabila dilakukan seleksi individu berdasarkan bobot lahir menghasilkan kemajuan genetik yang cepat (Falconer dan Mackay, 1996). Namun demikian tidak disarankan seleksi berdasarkan bobot lahir karena akan menyebabkan dystocia pada keturunannya.

Estimasi heritabilitas sifat bobot lahir pada Tabel 4 dengan metode pola tersarang sebesar $0,89 \pm 0,48 \quad\left(\mathrm{~h}_{\mathrm{S}}^{2}\right), \quad-0,11 \pm 0,33 \quad\left(\mathrm{~h}_{\mathrm{D}}^{2}\right), \quad$ dan $0,39 \pm 0,28\left(h_{S+D}^{2}\right)$. Pada pengukuran heritabilitas dari komponen induk melalui pola tersarang mempunyai nilai negatif hal ini disebabkan oleh tingginya nilai keragaman bobot lahir anak antar induk dan jumlah saudara kandung biasanya terlalu sedikit untuk mendapatkan taksiran yang realistis. Beberapa faktor yang mempengaruhi adalah kondisi intra-uterin (lingkungan fetus), genotip induk dan anak, lingkungan induk, paritas, nutrisi, jenis kelamin dan umur induk (Hansard dan Berry, 1969). Gruenwald (1967) menyatakan bahwa pertumbuhan fetus selama proses kebuntingan dipengaruhi oleh faktor genetis dari fetus sendiri dan pasokan zat gizi makanan dari induk. Faktor genetik, jumlah anak sekelahiran, jenis kelamin, status gizi dan kondisi kesehatan induk dapat menimbulkan keragaman bobot sepertiga akhir kebuntingan. 
Tabel 4. Nilai heritabilitas bobot lahir, bobot sapih, dan ADG pra sapih (the heritability of birth weight, weaning weight and $A D G$ pre-weaning)

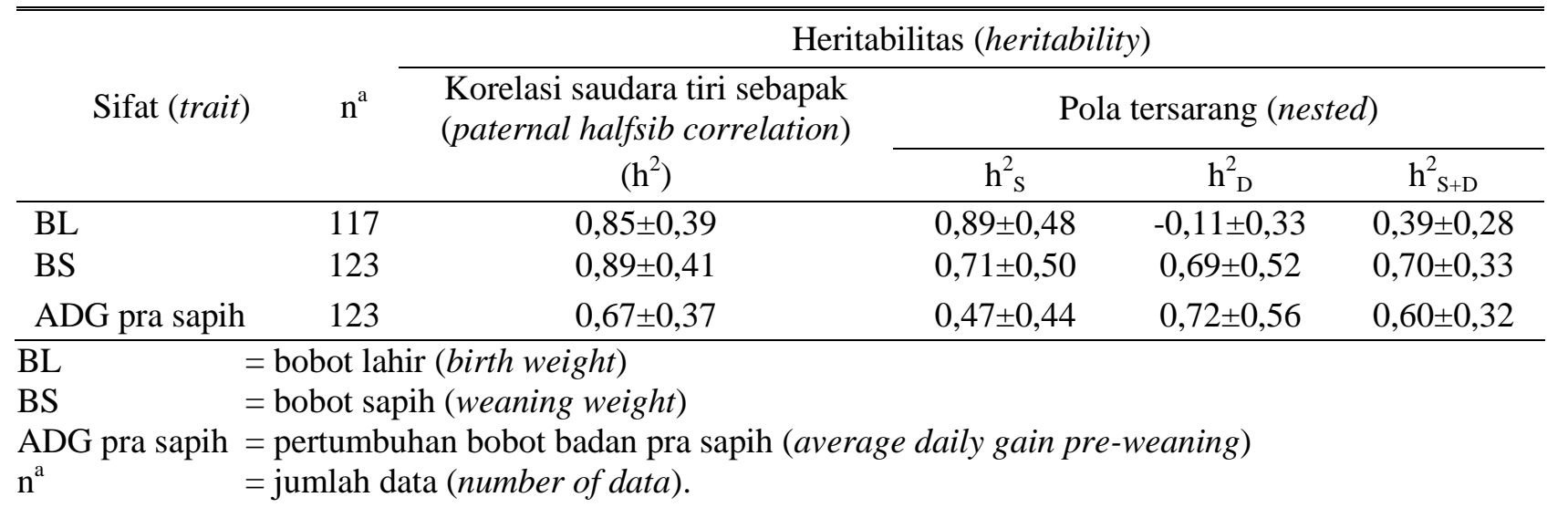

Estimasi heritabilitas bobot sapih. Estimasi heritabilitas sifat bobot sapih yang dianalisis dengan metode pola tersarang sebesar $0,71 \pm 0,50\left(\mathrm{~h}^{2}\right)$, $0,69 \pm 0,52\left(\mathrm{~h}_{\mathrm{D}}^{2}\right)$, dan $0,70 \pm 0,33\left(\mathrm{~h}_{\mathrm{S}+\mathrm{D}}^{2}\right)$, sedangkan nilai heritabilitas yang diestimasi dengan metode korelasi saudara tiri sebapak sebesar $0,89 \pm 0,41$. Nilai heritabilitas yang diperoleh dalam penelitian ini tergolong positif dan tinggi. Nilai heritabilitas bobot sapih yang positif dan tinggi menunjukkan tingginya keragaman yang diakibatkan pengaruh genetik aditif terhadap suatu sifat sedangkan selebihnya diakibatkan pengaruh genetik non aditif. Nilai heritabilitas yang diperoleh ini dapat digunakan sebagai kriteria seleksi.

Estimasi heritabilitas ADG pra sapih. Nilai heritabilitas pada pertumbuhan bobot badan harian fase pra sapih DEG menggunakan metode pola tersarang sebesar $0,47 \pm 0,44\left(\mathrm{~h}^{2}\right), 0,72 \pm 0,56\left(\mathrm{~h}^{2}\right)$, dan $0,60 \pm 0,32\left(\mathrm{~h}_{\mathrm{S}+\mathrm{D}}^{2}\right)$. Untuk analisis menggunakan metode korelasi saudara tiri sebapak sebesar $0,67 \pm 0,37$. Perbedaan nilai heritabilitas dan salah baku pertumbuhan sebelum sapih yang diestimasi dengan metode yang berbeda disebabkan perbedaan kemampuan kedua metode dalam memisahkan keragaman genetik dari keragaman non genetik untuk menduga besarnya angka pewarisan.

Hasil estimasi heritabilitas dari sifat bobot lahir, bobot sapih maupun pertumbuhan pra sapih DEG di UPT PT-HMT Garahan, Jember menggunakan metode korelasi saudara tiri sebapak dan pola tersarang termasuk dalam kategori tinggi. Nilai heritabilitas termasuk kategori tinggi apabila lebih besar dari 0,30 (Turner dan Young, 1969).

Heritabilitas yang diestimasi dengan menggunakan metode saudara tiri sebapak menghasilkan nilai heritabilitas yang tinggi dengan standard error yang rendah dibandingkan mean (rerata) karena metode ini banyak melibatkan ragam aditif yang penting untuk proses seleksi dan sedikit melibatkan ragam epistasis, tidak ada pengaruh ragam dominan dan lingkungan maternal sehingga hasil estimasi mendekati nilai sesungguhnya (Falconer dan Mackay, 1996; Warwick et al., 1990). Standard error yang rendah menunjukkan kecermatan yang tinggi. Dengan demikian nilai heritabilitas tersebut menunjukkan kemampuan yang diwariskan oleh tetuanya sehingga dapat digunakan untuk proses seleksi karena keterandalannya bagus.

Heritabilitas masing-masing sifat yang diestimasi dengan metode saudara tiri sebapak dalam penelitian ini lebih tinggi daripada yang diestimasi dengan metode pola tersarang karena perbedaan kemampuan kedua metode dalam memisahkan komponen keragaman. Metode saudara tiri sebapak hanya memisahkan keragaman menjadi komponen keragaman pejantan dan keragaman anak pejantan. Komponen keragaman pejantan terdiri dari $1 / 4$ keragaman genetik aditif. Pada pola tersarang, sumber keragaman berasal dari keragaman pejantan, keragaman induk, keragaman anak, keragaman pejantan dan induk. Komponen keragaman pejantan pada metode saudara tiri sebapak. Komponen keragaman induk pada pola tersarang terdiri dari $1 / 4$ keragaman genetik aditif 1/16 keragaman genetik dominan (Becker, 1992).

Pemisahan komponen keragaman yang lebih rinci dalam estimasi pola tersarang mengakibatkan rendahnya nilai estimasi heritabilitas dan standard error. Pemisahan komponen keragaman yang hanya terdiri dari komponen pejantan dan anak menghasilkan estimasi heritabilitas yang lebih tinggi dengan standard error yang lebih tinggi dibandingkan dengan estimasi menggunakan pola tersarang. Standard error tersebut tidak lebih tinggi dari nilai mean (rerata) sehingga untuk seleksi keterandalannya cukup bagus. Pada estimasi heritabilitas dengan metode saudara tiri sebapak hanya diperoleh satu nilai heritabilitas, sedangkan dengan metode pola tersarang dapat diperoleh tiga nilai heritabilitas, masing-masing berdasarkan komponen pejantan, komponen induk, serta komponen induk dan pejantan (Becker, 1992). 
Estimasi $\mathrm{h}^{2}{ }_{\mathrm{BL}}, \mathrm{h}^{2}{ }_{\mathrm{BS}}$, dan $\mathrm{h}^{2}{ }_{\mathrm{ADG}}$ Prasapih yang diestimasi dengan metode saudara tiri sebapak maupun saudara kandung menunjukkan nilai heritabilitas yang tinggi. Nilai heritabilitas yang tinggi pada suatu sifat menunjukkan adanya korelasi yang tinggi antara ragam genotip aditif dan ragam fenotip sehingga seleksi terhadap sifat tersebut sangat efektif untuk dilakukan (Lasley, 1978). Secara umum hasil tersebut lebih tinggi dari penelitian Kusumo (2004) pada tempat yang sama menghasilkan $\mathrm{h}^{2}$ bobot lahir, bobot sapih dan ADG pra sapih masing-masing sebesar 0,041 $\pm 0,26$, $-0,16 \pm 0,19$, dan $-0,22 \pm 0,18$.

\section{Kesimpulan dan Saran}

\section{Kesimpulan}

Berdasarkan analisis estimasi nilai heritabilitas sifat pertumbuhan DEG di UPT PTHMT Garahan, Jember yang meliputi bobot lahir, bobot sapih, dan pertumbuhan pra sapih tergolong tinggi, sehingga sifat-sifat pertumbuhan tersebut dapat digunakan sebagai salah satu kriteria dalam penyusunan program seleksi untuk meningkatkan produktivitas.

\section{Saran}

Usaha untuk mendapatkan estimasi nilai heritabilitas yang lebih handal diperlukan jumlah data keturunan yang banyak minimal 500 ekor. Metode analisis yang tepat menggunakan ternak domba lebih andal menggunakan metode korelasi saudara tiri sebapak (paternal halfsib correlations). Proses seleksi yang dilakukan di UPT PT-HMT Garahan, Jember sebaiknya juga lebih diperhatikan kembali. Cempe yang akan digunakan sebagai replacement harus memenuhi kriteria yang ingin dicapai. Hal ini dapat dilihat melalui catatan atau recording produksi maupun reproduksi. Catatan atau recording tersebut juga berguna untuk mengetahui silsilah ternak agar terhindar dari perkawinan inbreeding yang dapat menurunkan produksi dan reproduksi ternak. Perbaikan manajemen recording dapat dilakukan dengan pencatatan secara computerize untuk mempermudah dalam pemeliharaan ternak.

\section{Daftar Pustaka}

Becker, A. 1992. Manual of Quantitative Genetics. $5^{\text {th }}$ ed. Academic Enterprises. Pullman. USA.

Edey, T. N. 1983. Tropical Sheep and Goat Production. Australia Universities International Development Program (AUIDP), Canberra.

Falconer, R. D. and T. F. C. Mackay. 1996. Introduction to Quantitative Genetics. Longman. Malaysia.

Gruenwald, P. 1967. Growth of the human fetus. In Advances in Reproductive Physiology. A. McLaren (ed). Vol. II. Academic Pres. New York.

Hafez, E. S. E and I. A. Dyer. 1969. Prenatal Growth. Animal Growth and Nutrition. Lea dan Febiger. Philadelphia.

Hansard, S. L. and R. K. Berry. 1969. Fetal nutrition. In Animal Growth and Nutrition. Hafez, E. S. E and I. A. Dyer (ed). Lea dan Febiger. Philadelphia.

Hardjosubroto, W. 1994. Aplikasi Pemuliabiakan Ternak di Lapangan. PT. Gramedia Sarana Indonesia. Jakarta.

Lasley, J. F. 1978. Genetics of Livestock Improvement. $3^{\text {rd }}$ ed. Prentice Hall, Inc. Englewood Cliffs. New Jersey.

Kusumo, C. 2004. Estimasi heritabilitas Domba Ekor Gemuk di Balai Pembibitan Ternak Grahan. Fakultas Peternakan Universitas Gadjah Mada. Yogyakarta.

Soeparno. 2009. Ilmu dan Teknologi Daging. Gadjah Mada Press. Yogyakarta.

Sumadi. 1985. Beberapa sifat produksi dan reproduksi dari berbagai bangsa sapi daging di ladang ternak. Tesis Magister Sains, Institut Pertanian Bogor. Bogor.

Toelihere, M. R. 1981. Fisiologi Reproduksi pada Ternak. Angkasa Bandung. Bandung.

Turner, H. N. and S. S. Y. Young. 1969. Quantitative Genetic in Sheep Breeding. Cornell University Press. Hongkong.

Warwick, E. J., J. M. Astuti, dan W. Hardjosubroto. 1990. Pemuliaan Ternak. Gadjah Mada Press. Yogyakarta. 